\title{
A tribute to Norman Talal
}

D r. Norman Talal, a longtime, preeminent authority on Sjogren's syndrome whose research offered novel perspectives on autoimmune diseases, died in his home in New York on April 24, 2015. For many decades after its first description, Sjogren's syndrome was known as a disease that caused dryness of the eyes and mouth that could lead to tooth and eye problems but was not in itself considered serious or debilitating. Talal (Figure 1) and his group were among the first to recognize that Sjogren's syndrome could also cause many other more serious and debilitating problems. $\mathrm{He}$ and his fellows, students, and associates have had a large role in shaping the modern view of Sjogren's syndrome and disseminating knowledge of Sjogren's and other autoimmune diseases throughout medicine. Talal's major contribution using experimental animal models was the exploration of the role played by female hormones in the development of autoimmune disorders.

Talal was born in Brooklyn, educated at New York City public schools, and received his B.A. in 1954 from Columbia College and his MD in 1958 from the College of Physicians and Surgeons of Columbia University. In that year, he wrote the first of his more than 350 medical and scientific publications. He trained at the Presbyterian Hospital, spent a fellowship year at the Pasteur Institute with Professor Pierre Grabar, worked with Dr. Elliott Osserman at the Columbia University College of Physicians and Surgeons, and then began his career at the NIH as a research associate with Gordon Tompkins. $\mathrm{He}$ became a senior investigator at the National Institute of Arthritis and Metabolic Diseases (now the National Institute of Arthritis and Metabolic and Skin Diseases) and published his first paper on Sjogren's syndrome with Dr. Joseph Bunim in 1964.

Over the next several decades, he and his students and fellows examined, cared for, and closely observed hundreds of patients with Sjogren's syndrome. They found virus-like structures in the salivary glands and helped use modern imaging techniques to observe the structure of those glands. They found that Sjogren's patients can develop lymphomas that are often malignant, as well as serious kidney disease, neurologic disease, and lifethreatening blood changes. Perhaps most importantly, he and his students and fellows studied the immune system of their patients and discovered that many abnormalities in Sjogren's syndrome closely resembled those in the more common disease systemic lupus erythematosus (SLE).

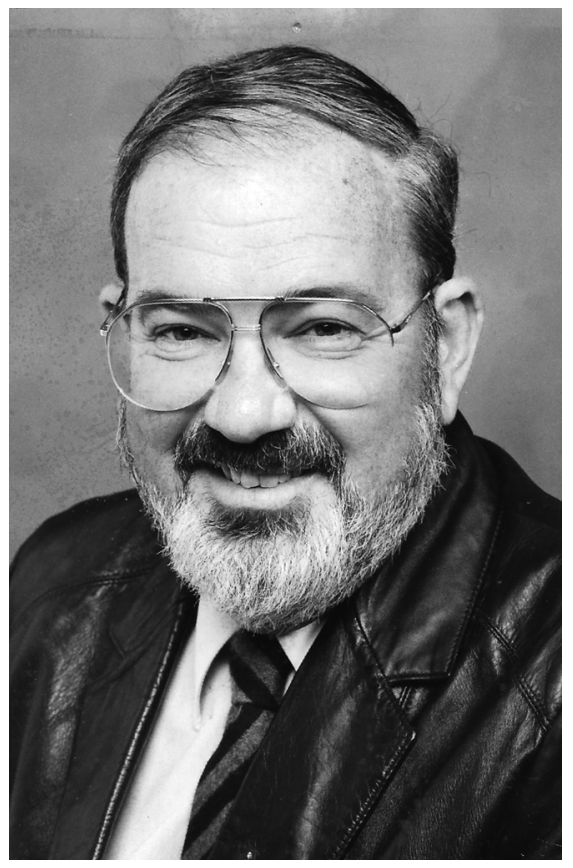

Figure 1. Norman Talal.

When he left the NIH in 1971, Talal carried on his medical career and his research studies as Professor of Medicine at the University of California at San Francisco and head of Rheumatology at the San Francisco VA Medical Center from 1971 to 1981 and then as Professor of Medicine and Microbiology and head of the Division of Clinical Immunology at the University of Texas in San Antonio. Although there was no animal equivalent of Sjogren's syndrome, Tala devoted his laboratory research program for the rest of his research career to the study of the immunologic abnormalities in mice that spontaneously developed SLE. Among the many immunologic problems he worked on, he devoted much of his attention to the still incompletely understood reasons that many autoimmune diseases, including SLE and Sjogren's syndrome, are far more common among females than among males. This sex disparity also holds true in most mouse models of lupus, and he and his colleagues and fellows wrote a number of important papers on that problem.

Talal trained 80 fellows and collaborated with many, including physicians and scientists from Japan, Europe, North and South America, Israel, Egypt, and China, as well as the United States. Among them were Leon Sokoloff, Alfred Steinberg, Theodore Pincus, Haralampos Moutsopoulos, William Seaman, James Balow, Paul Plotz, Susumu Sugai, Takao Koike, and Shigemasa Sawada. Many had distinguished careers, rose to professorships, and led research and/or clinical divisions. Of particular note, six of his seven Japanese fellows rose to professorships in major medical universities.

He strove for excellence and asked the same of his students. Talal was the recipient of the 1975 Philip Hench Award of the United States Pubic Health Service for his work in rheumatology, and in 1980, he won the William S. Middleton Award, the top award for medical research of the Veterans Administration. Over the years, he received awards from the Arthritis Foundation and the Hong Kong Society of Rheumatology, and several honorary doctorates from Europe and Japan. Talal was a member of the American Society for Clinical Investigation and served as vice president of the society in 1979-1980. He was also a member of the Association of American Physicians. He was active for many years in the Bay Area Council on Soviet Jewry on behalf of refuseniks, particularly Anatoly Scharansky.

Talal was a broadly educated, enthusiastic art lover and collector. The shelves in his home were crowded with preColumbian art and other ancient art and artifacts, including tribal statues from New Guinea, huacas from Peru, clay jugs and beads from Ecuador, and 3,000-year- 
old religious objects from the First Temple period in Israel. He also delightedly collected almost 300 match-safes made out of various materials - gold, silver, brass, leather - fashioned into miniature trunks, outhouses, even overalls. And he told jokes brilliantly.

Suffering toward the end of his life from several debilitating diseases, he returned to New York in 2000 and taught courses on achieving wellness through the arts with his wife, poet Dr. Marilynn Talal.

He is survived by his wife; a daughter, Melissa Talal, of Boston; a son, Dr. Andrew Talal, Professor of Medicine and chief of the Department of Gastroenterology and Hepatology at SUNY Buffalo; a daughterin-law, Dr. Marianthi Markatou; a granddaughter, Lillian; and many loving cousins and friends.
Haralampos M. Moutsopoulos, Marilynn Talal, and Paul H. Plotz

Department of Pathophysiology, School of Medicine, University of Athens, Athens, Greece (H.M. Moutsopoulos). National Institute of Arthritis and Musculoskeletal and Skin Diseases, NIH, Bethesda, Maryland, USA. E-mail: plotzp@arb.niams.nih. gov (P.H. Plotz). 